\title{
Semi-automatic determination of lead in whole blood
}

\author{
H. T. DELVES AND P. VINTER \\ From The Institute of Child Health, The Hospital for Sick Children, \\ Great Ormond Street, London
}

SYNOPSIS The procedure developed by Browett and Moss (1964) for the semi-automatic determination of the lead content of urine has been adapted for the determination of lead in blood.

Determinations are normally carried out in duplicate on $2.0 \mathrm{ml}$. samples of whole blood and the minimum sample size is $0.5 \mathrm{ml}$. The organic substances present in blood are destroyed by a manual wet-oxidation procedure and the lead is determined colorimetrically as lead dithizonate using a Technicon AutoAnalyzer.

The lower limit of detection, expressed as three times the standard deviation of the blank value, is $5 \mu \mathrm{g} . \mathrm{Pb} / 100 \mathrm{ml}$. blood. The standard deviation of the method in the upper range of normal blood lead level of $30 \mu \mathrm{g}$. Pb/100 ml. blood (Moncrieff, Koumides, Clayton, Patrick, Renwick, and Roberts, 1964), is $\pm 3 \mu \mathrm{g}$. $\mathrm{Pb} / 100 \mathrm{ml}$. blood.

Ten samples per hour may be estimated in duplicate.

The determination of lead in blood is an important diagnostic aid in the detection of lead poisoning (Moncrieff et al., 1964). This paper is concerned with the application to blood analysis of the partially automated procedure for the determination of urine lead recently developed by Browett and Moss (1965).

\section{MATERIALS AND APPARATUS}

PRECAUTIONS Prepare reagents and wash glassware with de-ionized water obtained by passing the water from a commercial de-ionizing kit through a column of mixed bed ion exchange resin.

Use Pyrex glassware throughout and pre-treat new glassware with chromic acid or boiling nitric acid. Wash glassware in general use with a $2 \%$ solution of R.B.S. 25 concentrate in water, rinse with water, and store under $10 \% \mathrm{v} / \mathrm{v}$ nitric acid until ready for use. Rinse once with low in lead (concentrated) nitric acid and wash thoroughly with water.

For the automatic analysis of lead solutions it is necessary to shield the dithizone reservoir bottle and the extractor coil from light.

REAGENTS The following reagents are the "low in lead for foodstuffs grade', containing $<0.005$ p.p.m. Pb; nitric acid, S.G. 1.42; perchloric acid, S.G. 1.54; sulphuric acid, S.G. 1.84; ammonia, S.G. 0.88; and potassium cyanide.

Other reagents required are citric acid, low in lead $<0.5$ p.p.m.; sodium sulphate, $\mathrm{Na}_{2} \mathrm{SO}_{3} 7 \mathrm{H}_{2} \mathrm{O}$, Analar grade; chloroform (May \& Baker, R. grade); dithizone (Eastman Kodak, Kirkby, Liverpool); lithium heparin, sterile 1,000 units/ml. (Boots Pure Drug Co. Ltd.).

Received for publication 11 January 1966.
Digestion mixture Cautiously add $50 \mathrm{ml}$. of sulphuric acid (S.G. 1.84) to $150 \mathrm{ml}$. of water in a 2-litre Pyrex conical flask. Cool and add $500 \mathrm{ml}$. of nitric acid (S.G. 1.42) followed by $300 \mathrm{ml}$. of perchloric acid (S.G. 1.54).

Acid ammonium citrate To approximately 1 litre of water add $400 \mathrm{~g}$. of citric acid and a few drops of phenol red indicator solution. Cautiously add approximately $400 \mathrm{ml}$. of ammonia solution (S.G. 0.88) until a pink solution is obtained ( $p \mathrm{H} \mathrm{8.4)}$. When this solution is cool, remove any lead present by extracting with successive approximately $150 \mathrm{ml}$. portions of $0.01 \% \mathrm{w} / \mathrm{v}$ solution of dithizone in chloroform until the organic phase remains green. Follow this by extracting with successive approximately $150 \mathrm{ml}$. portions of chloroform to remove the excess dithizone from the aqueous phase, until the organic phase is colourless. Allow the excess chloroform to evaporate by leaving the solution loosely covered overnight. Transfer the ammonium citrate solution to a 5 litre volumetric flask containing $50 \mathrm{ml}$. of nitric acid (S.G. 1.42 ) in approximately 2 litres of water, and make up to volume with water.

Buffer solution Dissolve 10 g. of $\mathrm{Na}_{2} \mathrm{SO}_{3} .7 \mathrm{H}_{2} \mathrm{O}$ in approximately $100 \mathrm{ml}$. of water. Add one drop of 0.88 S.G. ammonia solution and remove the lead from the solution as described for the ammonium citrate solution. Transfer the sulphite solution to a 1-litre volumetric flask containing $15 \mathrm{ml}$. of ammonia solution (S.G. 0.88) and approximately $200 \mathrm{ml}$. of water, add $2.5 \mathrm{~g}$. potassium cyanide dissolved in approximately $100 \mathrm{ml}$. water, and make up to volume with water.

Stock standard lead solution (1 mg. Pb/ml.) Dissolve $160.0 \mathrm{mg}$. dried $\left(105^{\circ}\right.$, overnight) $\mathrm{Pb}\left(\mathrm{NO}_{3}\right)_{2}$ in water. Add $5 \mathrm{ml}$. of nitric acid (S.G. 1.42) and make up to $100 \mathrm{ml}$. with water.

Working standard lead solutions Make a $10 \mu \mathrm{g} . \mathrm{Pb} / \mathrm{ml}$. 
solution by diluting the stock with acid ammonium citrate solution, and from this make up solutions containing 0.05 to $0.30 \mu \mathrm{g}$. $\mathrm{Pb} / \mathrm{ml}$. using acid ammonium citrate solution as diluent. This range corresponds to 15 to $90 \mu \mathrm{g} . \mathrm{Pb} / 100 \mathrm{ml}$. blood.

Dithizone Dissolve $5 \mathrm{mg}$. of dithizone in 1 litre of chloroform. Prepare on day of use.

APPARATUS To prepare the samples, disposable plastic syringes, $10 \mathrm{ml}$. capacity (Baileys Sterile Syringes Ltd.); $2.00 \mathrm{ml}$. pipettes, grade $\mathrm{B}$, calibrated to contain $2.00 \mathrm{ml}$.; $50 \mathrm{ml}$. Pyrex conical flasks (narrow necked); and a thermostatically controlled sand bath are required.

Automatic lead estimation Technicon AutoAnalyzer sampler, pump, S-type colorimeter and recorder. The following items are not available from Technicon Instrument Co. Ltd. and were developed specifically for the automatic analysis of lead solutions by Browett and Moss (1965). They are now available from Aimer Products Ltd., Camden Town, N.W.1.

1 Extractor coil; horizontal flat spiral made from 10 feet of $2.7 \mathrm{~mm}$. I.D. Pyrex glass tubing.

2 Flow cell: $10 \mathrm{~mm}$. light path rectangular flow cell.

3 Phase separator; modified B.2 phase separator for use in conjunction with flow cell.

The tubular flow cell used in the Technicon $\mathbf{N}$ type colorimeter is unsatisfactory for this determination (Browett and Moss, 1965). A modification kit can be purchased from Technicon Instrument Co. Ltd. for the conversion of the $\mathbf{N}$ type colorimeter to the $\mathrm{S}$ type which is used with the rectangular flow cell.

A mask made from a $25 \times 20 \mathrm{~mm}$. piece of Ademco black photographic mounting board with an $11 \mathrm{~mm}$. $\times$
$3 \mathrm{~mm}$. rectangular hole cut in its centre is fitted around the flow cell so only that light passing through the flow cell falls upon the photo-cell detector.

METHOD Rinse the disposable plastic syringe with sterile lithium heparin solution and take the blood by venepuncture. Mix well to prevent clotting, leave in the syringe with the needle bent back and inserted into a cork, and send to the laboratory for analysis.

Place the syringe in the freezer compartment of a refrigerator for upwards of $30 \mathrm{~min}$. depending on the temperature setting of the refrigerator. (Urgent samples may be frozen by using small pieces of solid carbon dioxide in a Dewar flask.) After complete freezing, allow the sample to thaw at room temperature.

Mix the haemolysed sample by shaking for approximately $30 \mathrm{sec}$. before pipetting $2.00 \mathrm{ml}$. into a Pyrex conical flask, washing the pipette out three times with water when the pipette should be free from traces of the sample, and collect the washings in the flask. Carry out the determinations in duplicate.

DIGESTION Add $10 \mathrm{ml}$. of the digestion mixture, mix, and place the flask on a sand-bath at $250^{\circ} \mathrm{C}$., until the solution has evaporated to dryness and no further evolution of $\mathrm{SO}_{3}$ is observed. This usually takes at least four hours and can conveniently be left overnight.

Allow the flask to cool, add $6.0 \mathrm{ml}$. (burette) of the acid ammonium citrate solution and allow to stand for not less than $30 \mathrm{~min}$. to ensure complete dissolution of the residue. During this time set up the AutoAnalyzer for the estimation of lead.

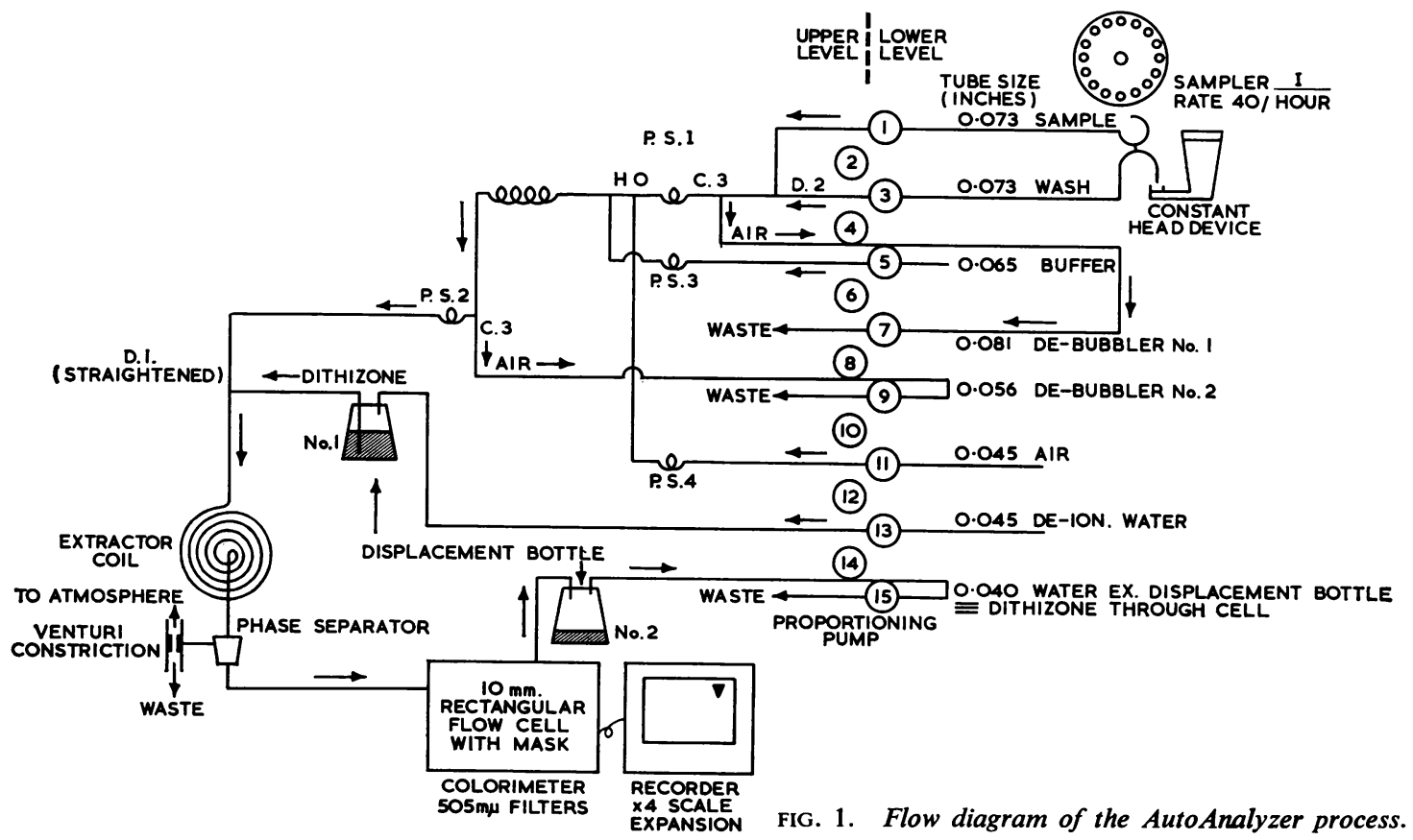


AUTOMATIC ANALYSIS OF LEAD SOLUTIONS Connect the system as shown in Figure 1. Set the sampler crook to the wash position, close the tap on the flow cell displacement bottle (no. 2) and disconnect the pump tubing (no. 15) from the transmission line to this bottle. Switch on the proportioning pump.

When an even flow pattern is established place a series of six sample cups, completely filled with the wash solution, in the sampler plate. Adjust the positions of the polythene sample tubes, which are connected to pump tubes 1 and 3 through the sample and wash arms of the sampler crook, respectively, so that in the sample position the end of the tube through the sampler arm is approximately $1 \mathrm{~mm}$. above the bottom of the sample cup, and the change over from wash to sample and sample to wash at D.2, is almost synchronous, with all the air in the system being pumped to waste via C.3.

Re-set the crook to the wash position, reconnect pump tube no. 15 to the flow cell displacement bottle line and open the tap on this bottle so that the organic phase is pumped through the cell.

Switch on the chart drive with the range expander set at $\times 4$, adjust the position of the flow cell to give a maximum percentage transmission reading, and, when a steady base line is established, place sample cups containing the working lead standard solutions in the sample plate alternately with cups filled with the wash solution. Switch on the sampler module.

When the calibration curve has been established, transfer the solutions to be analysed to the sample cups, place these alternately with wash cups in the sampler plate and place two standard lead solutions after every 20 estimations as a check on the stability of the system.

Draw a calibration curve of peak height versus lead concentration of the working standard solutions and use this to determine the concentration of lead in the blood digest solutions. If the lead concentration of the blood digest solution exceeds $120 \mu \mathrm{g} . / 100 \mathrm{ml}$. repeat the colorimetric estimation with a suitable dilution in acid citrate solution.

\section{RESULTS}

CALIBRATION CURVE For the concentration range $15-90 \mu \mathrm{g}$. $\mathrm{Pb} / 100 \mathrm{ml}$. blood the calibration curve is shown in Fig. 2 and is almost linear. Blood lead

TABLE I

RECOVERY OF LEAD ADDED TO BLOOD SAMPLES

\begin{tabular}{lcc}
$\begin{array}{l}\text { Lead Added } \\
(\mu \mathrm{g} . / 100 \mathrm{ml} .)\end{array}$ & $\begin{array}{l}\text { Lead Recovered } \\
(\mu \mathrm{g} . / 100 \mathrm{ml} .)\end{array}$ & $\begin{array}{l}\text { Recovery } \\
(\%)\end{array}$ \\
\hline 10 & $10 \pm 2(3)$ & 100 \\
20 & $21 \pm 2(3)$ & 105 \\
30 & $30 \pm 3(3)$ & 100 \\
43 & $38 \pm 4(3)$ & 88 \\
50 & $47 \pm 1(3)$ & 94 \\
60 & $61 \pm 5(3)$ & 102 \\
60 & $63 \pm 6(4)$ & 105 \\
70 & $66 \pm 1(3)$ & 94 \\
86 & $86 \pm 7(3)$ & 100 \\
129 & $120 \pm 0(3)$ & 93
\end{tabular}

Mean \pm S.D. (number of replicate analyses).

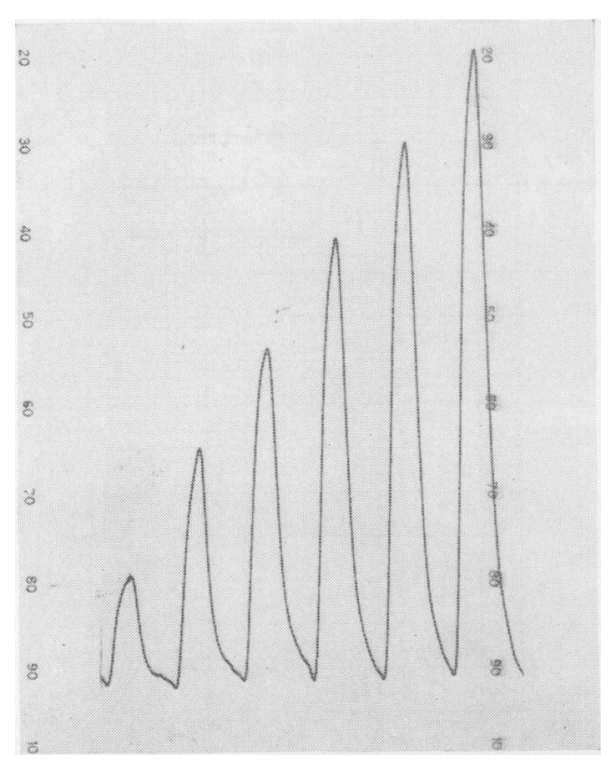

FIG. 2. Calibration with standards equivalent to 15,30 , 45, $60 \mu \mathrm{g} . \mathrm{Pb} / 100 \mathrm{ml}$. blood $\times 4$ scale expansion.

levels are obtained using the Technicon chart reader.

The recovery of lead added to blood samples is shown in Table $I$ and is quantitative over a wide range of lead concentrations.

LOWER LIMIT OF DETECTION The standard deviation of nine replicate blank estimations, of which the mean was $7.4 \mu \mathrm{g}$. $\mathrm{Pb} / 100 \mathrm{ml}$. blood, was $\pm 1.8 \mu \mathrm{g}$./ $100 \mathrm{ml}$. Thus the lower limit of detection expressed as three times the standard deviation of the blank value is 5.4 or approximately $5 \mu \mathrm{g}$. $\mathrm{Pb} / 100 \mathrm{ml}$. blood.

REPRODUCIBILITY Figure 3 shows the necessity for haemolysis. The reproducibility obtained with the unhaemolysed sample is poor compared with that obtained with the haemolysed sample.

The results obtained for replicate analysis of a blood sample haemolysed by freezing and thawing and a (different) blood sample haemolysed by dilution with water were $30 \mu \mathrm{g} . / 100 \mathrm{ml}$., S.D. $\pm 2.9 \mu \mathrm{g} . /$ $100 \mathrm{ml}$. (11 replicates), and $32 \mu \mathrm{g} . / 100 \mathrm{ml}$. S.D., \pm $2.6 \mu \mathrm{g} . / 100 \mathrm{ml}$. (nine replicates) respectively.

The good agreement between duplicate estimations obtained in routine application is shown in Figure 4.

EFFECT OF SULPHURIC ACID IN THE DIGESTION MIXTURE If sulphuric acid is omitted from the digestion mixture low blood lead values are obtained. Ten replicate analyses of a blood sample were carried out using both the normal digestion mixture and with sulphuric acid omitted from the digestion mixture. 


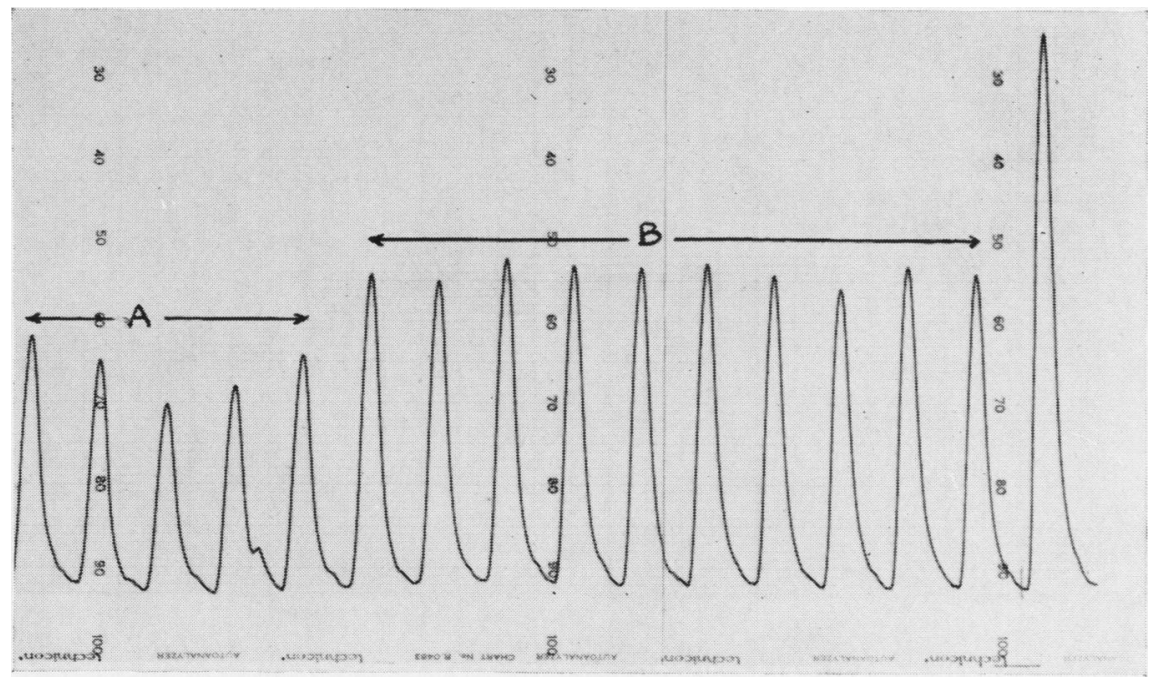

FIG. 3. The effect of haemolysis of the blood sample. Series $A$ results were obtained on haemolysed blood, series $B$ on haemolysed blood. The last result is from a $90 \mu \mathrm{\mu g} / 100 \mathrm{ml}$. standard. $\times 4$ scale expansion.

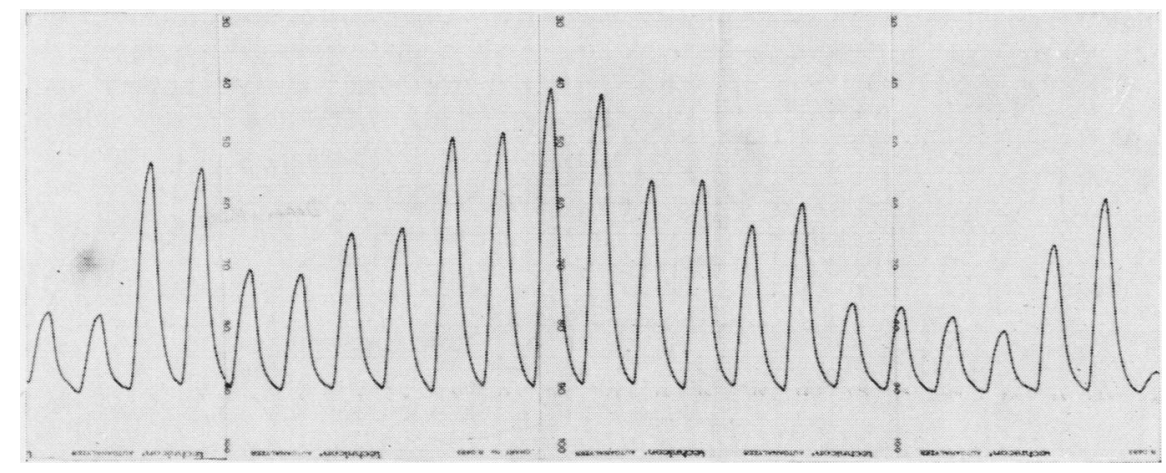

FIG. 4. Duplicate analyses on a sequence of blood specimens.

The mean values obtained were $33 \mu \mathrm{g} . / 100 \mathrm{ml}$. (S.D. $\pm 4 \mu \mathrm{g} . / 100 \mathrm{ml}$.) and $21 \mu \mathrm{g} . / 100 \mathrm{ml}$. (S.D. \pm $3 \mu \mathrm{g} . / 100 \mathrm{ml}$.) respectively. When $30 \mu \mathrm{g}$. $/ 100 \mathrm{ml}$. of a lead standard was added to a blood sample only $21 \mu \mathrm{g} . / 100 \mathrm{ml}$. (S.D. $\pm 1 \mu \mathrm{g} . / 100 \mathrm{ml}$.) (10 replicates) was recovered when sulphuric acid was omitted from the digestion mixture.

EFFECT OF MASKING THE OPTICAL CELL A standard lead solution was continuously aspirated into the AutoAnalyzer system with the flow cell masked and then with the mask removed. The results (Fig. 5) show that the use of the mask gives an improved sensitivity of approximately $11 \%$.

INTERFERENCES Standard solutions of thallium and bismuth in both acid citrate solution and an acid citrate solution of a digested blood sample ('blood digest solution') were analysed for their apparent lead content. The results are shown in Table II.
TABLE II

INTERFERENCE BY BISMUTH AND THALLIUM

\begin{tabular}{llcc} 
Metal & Solution & $\begin{array}{l}\text { Metal } \\
(\mu \mathrm{g} . / 100 \mathrm{ml} . \\
\text { blood })\end{array}$ & $\begin{array}{l}\text { Apparent Lead } \\
\text { Content } \\
(\mu \mathrm{g} . \mathrm{Pb} / 100 \mathrm{ml} . \\
\text { blood })\end{array}$ \\
\hline $\mathrm{Bi}$ & Acid citrate & 42 & 16 \\
$\mathrm{Bi}$ & Blood digest solution & 46 & 16 \\
$\mathrm{Tl}$ & Acid citrate & 86 & $3^{1}$ \\
T1 & Blood digest solution & 416 & $10^{1}$ \\
& & 416 & 15 \\
\end{tabular}

${ }^{1}$ The value obtained after subtracting the lead content of the blood digest solution.

COMPARISON WITH MANUAL METHODS Seventeen blood samples were analysed by the semi-automated procedure described here, and for comparison 11 were analysed by the authors using the manual pro- 


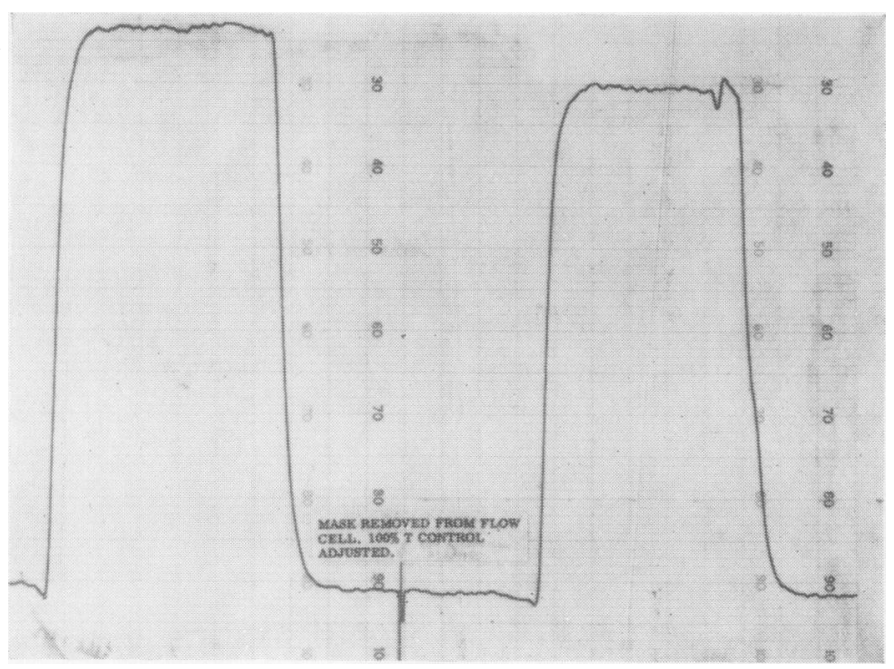

FIG. 5. The effect of masking the flow cell when $75 \mu \mathrm{g} . / 100 \mathrm{ml}$. blood standard solution was continuously aspirated first with the mask in position and then with the mask removed.

cedure described by Vinter (1964) and six by an independent hospital (Smith, 1966) using the method of Blaxter and Allcroft (1950). The results are shown in Table III.

\section{TABLE III}

COMPARISON WITH MANUAL METHODS

Sample Blood Lead Concentration ( $\mu \mathrm{g} . / 100 \mathrm{ml}$ )

\begin{tabular}{|c|c|c|c|c|}
\hline & \multicolumn{2}{|c|}{ Manual Methods } & \multicolumn{2}{|c|}{ Semi-automatic Method } \\
\hline $\begin{array}{r}1 \\
2 \\
3 \\
4 \\
5 \\
6 \\
7 \\
8 \\
9 \\
10 \\
11\end{array}$ & $\begin{array}{l}\text { Method } \\
\text { of Vinter } \\
(1964)^{1} \\
\mathbf{M}_{1}\end{array}$ & $\begin{array}{l}12 \\
14 \\
21 \\
22 \\
22 \\
29 \\
29 \\
50 \\
52 \\
68 \\
94\end{array}$ & $\mathbf{A}$ & $\begin{array}{r}17 \\
20 \\
22 \\
23 \\
21 \\
19 \\
27 \\
60 \\
58 \\
64 \\
107\end{array}$ \\
\hline $\begin{array}{l}12 \\
13 \\
14 \\
15 \\
16 \\
17\end{array}$ & $\begin{array}{l}\text { Method } \\
\text { of Blaxter } \\
\text { and Allcroft } \\
(1950)^{2} \\
\mathbf{M}_{2}\end{array}$ & $\begin{array}{r}25 \\
32 \\
43 \\
60 \\
68 \\
159\end{array}$ & $\mathbf{A}$ & $\begin{array}{r}22 \\
45 \\
46 \\
70 \\
64 \\
165\end{array}$ \\
\hline
\end{tabular}

${ }^{1}$ Analyses carried out at the Hospital for Sick Children, Great Ormond Street.

2Analyses carried out at Chase Farm Hospital, Enfield, Middlesex (Smith, 1966).

Regression: $A=1.077 \mathrm{M}_{1}-0.055$. Slope differs from unity, difference due to error, is 0.044 . $(P=0.05)$. Intercept not significantly different from zero.

$A=1,016 \mathrm{M}_{2}+3 \cdot 17$. Slope not significantly different from unity; intercept is significantly different from zero difference due to error is $1.93(P=0.05)$.

The Association of Clinical Biochemists scientific study group on automation in clinical chemistry (Northam, 1965) recommend that any published method involving the AutoAnalyzer should include information on the working performance and whether the individual modules and pump tubes conform to specification. Over the past year we have found that the variations in the calibration curve resulting from different sets of pump tubing are of no practical significance. Of the remaining recommendations, only that of the pump speed is applicable. This was found to be $15 \mathrm{sec}$./revolution.

\section{DISCUSSION}

MANIPULATION OF BLOOD Of the lead present in blood, $90-95 \%$ is bound to the red cells (HaegerAronsen, 1960) and it is important to analyse whole blood rather than plasma. However, even vigorous shaking of a blood specimen is insufficient to render it homogenous long enough for truly representative samples to be taken, as shown in Figure 3. If the specimen is haemolysed the intracellular fluid can freely mix with the plasma and shaking will produce a homogenous solution. Of the two methods of haemolysis mentioned, freezing and thawing is to be preferred because this is accomplished without removing the specimen from the syringe and without adding any reagents, thus precluding any risk of contamination. There is no significant difference between the reproducibility obtained with replicate analyses of a blood sample haemolysed by freezing and thawing and a blood sample haemolysed by dilution with a large volume of water.

Although the volume of blood recommended, $2 \mathrm{ml}$., is ample for accurate results in the normal range, it is possible to reduce the volume to $0.5 \mathrm{ml}$. and still retain satisfactory accuracy at the upper limit of normal. 
THE DIGESTION MIXTURE Sandell (1959) recommended avoiding the use of sulphuric acid in the digestion mixture for the determination of lead in biological materials because of possible losses of lead by occlusion of lead sulphate with slightly soluble calcium sulphate. On the contrary, the Analytical Methods Sub-committee of the Society of Analytical Chemistry (1959) recommended the use of sulphuric acid. Our observations support the latter recommendation, since the recovery of lead present in blood and added to blood is low (64 to $73 \%$ ) if sulphuric acid is omitted from the digestion mixture.

COLORIMETRIC ESTIMATION OF LEAD The procedure used for the automatic colorimetric estimation of lead is that developed by Browett and Moss (1965), where lead is extracted as lead dithizonate into a chloroform solution of dithizone from an aqueous phase of approximately $p \mathrm{H} \mathbf{9 \cdot 0}$. Cyanide ions in the aqueous phase inhibit all cationic interferences except stannous tin, thallium, and bismuth (Sandell, 1959). Tin is oxidized to stannic tin during the digestion of the sample and its effects can be ignored, and Browett and Moss selected the $p \mathrm{H}$ for the extraction of lead dithizonate so as to minimize any interference from bismuth. Furthermore, as these authors showed in their work on bismuth and urine ash solutions, the interference from thallium and bismuth is further lowered by the presence of salts (Table III) from the digested samples.

Some minor modifications were made to the original manifold system of Browett and Moss (1964). These were the inclusion of the pulse suppressor (P.S.I. of Fig. 1) to ensure complete removal of the air from the sample/wash system by the first debubbler, and an increase in the flow rate of the organic phase in the extractor coil from $0.6 \mathrm{ml} . / \mathrm{min}$. to $0.8 \mathrm{ml} . / \mathrm{min}$. to obtain a more even flow pattern.
The flow rate of the organic phase through the flow cell was consequently increased from 0.42 to $0.6 \mathrm{ml} . / \mathrm{min}$. A third modification was the use of a mask with the optical flow cell resulting in a $11 \%$ improvement of sensitivity with no loss in stability (Fig. 6).

The method described has been used for the past year for all routine blood lead analyses carried out at this hospital and has been found to be very reliable. Blood lead results from patients are interpreted in relation to the normal values of Moncrieff et al. (1964), since their method and the present method give substantially the same results (Table IV).

Our grateful thanks are due to Dr. B. E. Clayton, consultant in charge of the Department of Chemical Pathology, Hospital for Sick Children, Great Ormond Street, for all her encouragement and interest. We are indebted to Mr. R. Moss and the late Mr. E. V. Browett, of Associated Octel Co. Ltd., for making available details of their procedure and results before publication, for giving prototypes of their flow cell and phase separator, and for permitting us to have copies made.

We are grateful to the anonymous donor of the AutoAnalyzer and to The People newspaper and the Nuffield Foundation for financial assistance.

\section{REFERENCES}

Blaxter, K. L., and Allcroft, R. (1950). J. comp. Path., 60, 133. Browett, E. V., and Moss, R. (1964). Personal communication. - - (1959). Analyst, 90, 715.

Haeger-Aronsen, B. (1960). Scand. J. clin. Lab. Invest., 12, suppl. $47,11$.

Moncrieff, A. A., Koumides, O. P., Clayton, B. E., Patrick, A. D. Renwick, A. G. C., and Roberts, G. E. (1964). Arch. Dis. Childh., 39, 1.

Northam, B. E. (1965). Association of Clinical Biochemists, 1965. Scientific Committee Study Group on Automation in clinical chemistry. Technical Bulletin No. 7.

Sandell, E. B. (1959). Colorimetric Determination of Traces of Metals, 3rd ed., pp. 555 and 582. Interscience, New York.

Society for Analytical Chemistry (1959). Analyst, 84, 127.

Smith, R. L. (1966). Personal communication.

Vinter, P. (1964). J. med. Lab. Technol., 21, 281. 